Vol. 3, No. 1, 2021

https://doi.org/10.23939/jtbp2021.01.051

Volodymyr Pashkevych ${ }^{1}$, Maksym Malashkin ${ }^{2}$, Vasyl Zhelykh ${ }^{3}$, Orest Lozynskyy

\title{
ASSESSMENT OF ENERGY SECURITY OF HIGHER EDUCATION INSTITUTIONS
}

\author{
Lviv Polytechnic National University, \\ ${ }^{1}$ Department of Electronics and Information Technolodgy, \\ ${ }^{2}$ Ukraine Energy Association, \\ Lviv Polytechnic National University, \\ ${ }^{3}$ Department of Heat, Gas Supply and Ventilation, \\ ${ }^{4}$ Department of Electrmehatronics and Computerized Electromechanical Systems, \\ vasyl.m.zhelykh@lpnu.ua
}

(C) Pashkevych V., Malashkin M., Zhelykh V., Lozynskyy O., 2021

The research work is devoted to the survey of the power economy of Lviv Polytechnic National University to assess energy security, to improve the strategy of energy use and to develop measures for improving the energy security of the university.

The first chapter provides a brief description of the proposed method of studying the energy security of the university. It is based on the method of determining 46 indicators according to which five criteria of energy security are formed: Energy efficiency, Energy independence, Energy security, Reliability of heat supply, Economic stability.

In the eighth chapter, according to the mentioned indicators the estimates of criteria are calculated and the analysis of their levels is carried out. Based on this analysis, the principles of improving the energy security of the university are proposed.

Key words: energy security, energy efficiency, energy independence, heating, reliability of heat supply, economic stability, fuel and energy resources.

\section{Introduction}

In today's conditions, sustainable economic development of any enterprise depends on the provision of its fuel and energy resources. Energy security is of paramount importance in this context. However, the essence of energy security of the enterprise nowadays is understood unilaterally, more as electrical security. Insufficient attention is paid to the introduction of energy-saving technologies and equipment at enterprises, stimulating energy savings and preventing their losses, the use of progressive indicators of standardization of specific costs of fuel and energy resources. To date, there are no clear and thorough methods for assessing the energy security of the enterprise. These unresolved issues do not allow to manage the security of the enterprise at the appropriate level, which has a negative impact on the results of its management (Kapitula et. al., 2010). This problematics is especially relevant for higher education institutions financed from the state budget.

Determining the level of energy security, based on the adopted general system of comprehensive indicators, is one of the conditions for sustainable socio-economic, material-and-technical development of 
higher education institutions should increase the attention of freelance managers to the problems associated with improving energy security.

The urgent need to create an effective management system for energy consumption and energy conservation in education and the importance of the results of energy security assessment to ensure the sustainable development of higher education institutions indicates the objective need for such surveys.

\section{Analysis of recent research and publications}

The study of energy security of enterprises is devoted to the work (Mazur, 2014; Methodical recommendations, 2013; Mazur, 2014; Mukolyuk, 2019; Lelyuk, 2013; Vorontsov et. al., 2012; Barannik, 2012) where aspects of energy security assessment of enterprises are considered. Most researchers assess the level of energy security by a small number of key indicators. Therefore, the proposed methodological approaches are uninformative to justify certain measures to improve energy security and select optimal solutions for the prospects for the development of higher education institutions. Particular attention should be paid to the development of a system of energy security indicators, which should provide a quantitative, comparative and relative assessment of its state and changes under the influence of certain factors that affect the interests in the energy sector. The essential characteristics of the latter should be reflected by indicators in the methodology of assessing the level of energy security and analysis of the impact of trendschanges in threats. The most thorough method of assessing the energy security of enterprises is given in research (Mazur, No.1, 2014), where the analysis of energy security of the heat supply enterprise is carried out. This technique best reflects the state of energy security for higher education institutions and can be used to assess the energy security of higher education institutions after minor adjustments.

\section{Research objective}

Research objective is to adapt existing methods of assessing the energy security of enterprises for higher education institutions and to develop measures of its' improving on the example of the energy sector of Lviv Polytechnic National University.

\section{Presentation of research material}

Energy security is a state of the economic system, which is characterized by the autonomy of energy resources, their efficient use, the availability of sufficient available for use fuel and energy resources, the absence of threats to destabilize the normal functioning of the university (Mazur, 2014). The relationship between the components of energy security is shown in the form of a diagram in Fig. 1.

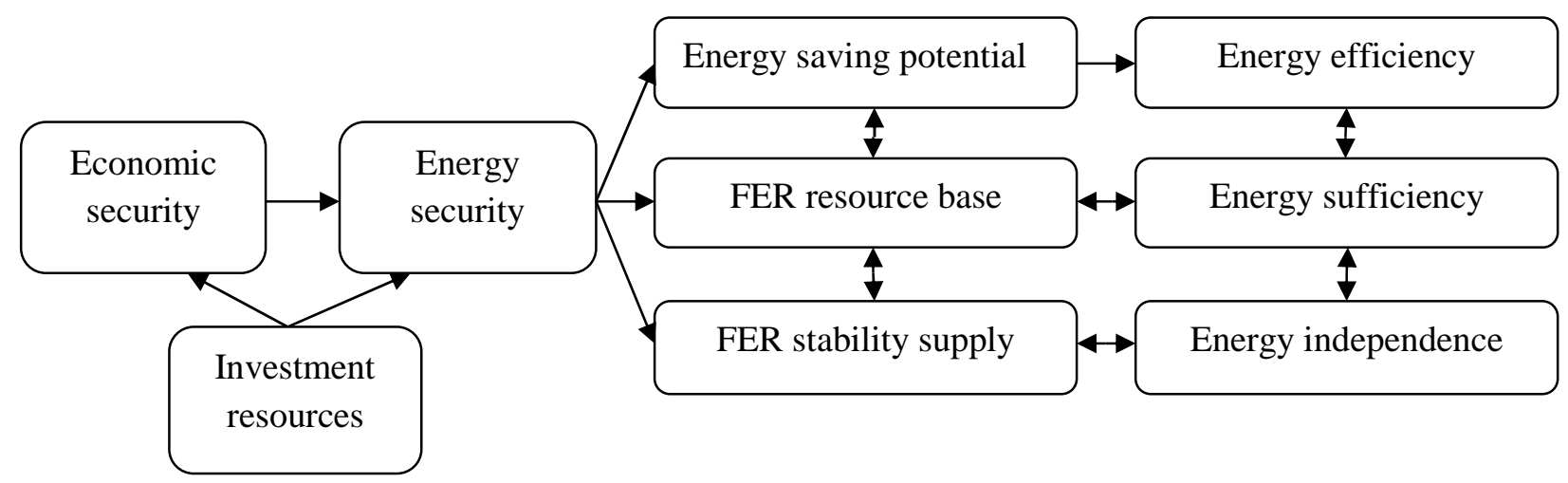

Fig. 1. The interrelationships between the components of energy security 
The methodology described in research (Mazur, 2014) involves the definition of 50 energy security indicators according to five criteria: "Energy efficiency", "Energy independence", "Energy security", "Reliability of heat supply", "Economic stability".

In the process of analysis of energy security indicators from the criterion of "Economic stability" the following indicators were excluded: "Tariff coverage ratio of the actual cost of providing services (K34)", "Consumer debt growth ratio for heat supply (K38)", "Share of thermal energy supply at market prices (K39)", "The share of budget organizations in the consumption of thermal energy (K41)", as these indicators can be applied only to heat supply companies. According to (Methodical recommendations, 2013; Mazur, 2014; Yemelyanov et. al., 2018; Yemelyanov et. al., 2019) the definition of the integrated indicator of energy security for each area of security is carried out according to the formula:

$$
m=\sum_{i=1}^{m} d_{i} \cdot y_{i},
$$

where $I_{m}$ - aggregate energy security index; $d_{i}$ - weighting factor that determines the degree of contribution of the $\mathrm{i}$-th indicator to the aggregate index; $y_{i}$-normalized score of the $\mathrm{i}$-th indicator

The calculation of weights is based on the results of expert evaluation by the formula:

$$
d_{i}=\frac{a_{i}}{\sum_{i=1}^{n} a_{i}}
$$

where $a_{i}$ - expert assessment, noting the importance of the $i$-th indicator for the aggregate energy security index.

Based on these indicators, the values of each of the above criteria were calculated (see Table 1) and energy security levels were determined for each of the five criteria (Table 2). Based on this analysis, the principles of improving the energy security of the university are proposed.

The results of the analysis of energy security indicators of Lviv Polytechnic National University are listed in the resulting Table 1.

Table 1

The results of the analysis of energy security indicators

\begin{tabular}{|c|c|c|c|c|c|c|}
\hline \multirow{2}{*}{ No } & \multirow{2}{*}{ Indicators } & \multirow{2}{*}{ Calculation method } & \multirow{2}{*}{$\begin{array}{c}\text { Source of } \\
\text { information }\end{array}$} & \multicolumn{3}{|c|}{ Years } \\
\hline & & & & 2017 & 2018 & 2019 \\
\hline 1 & 2 & 3 & 4 & 5 & 6 & 7 \\
\hline \multicolumn{7}{|c|}{ Energy Efficiency Criterion } \\
\hline 1 & $\begin{array}{l}\text { Energy productivity } \\
\text { (energy conversion } \\
\text { factor), t. of conv. fuel } \\
\text { (K1) }\end{array}$ & $\begin{array}{c}\text { Production and } \\
\text { supply of thermal } \\
\text { energy, kg. of conv. } \\
\text { fuel } \\
\text { FER costs, kg. of } \\
\text { conv. fuel }\end{array}$ & $\begin{array}{c}\text { f.11- mtp } \\
\text { f. } 4-\text { mtp (annual) }\end{array}$ & 0.886 & 0.886 & 0.885 \\
\hline 2 & $\begin{array}{l}\text { Actual (regulatory) } \\
\text { specific costs of } \\
\text { conventional fuel for the } \\
\text { production of } 1 \text { Gcal of } \\
\text { heat, } \\
\text { kg. of conv. fuel/Gcal }\end{array}$ & $\begin{array}{l}\text { FER costs, kg. of } \\
\text { conv. fuel } \\
\text { Production and } \\
\text { supply of thermal } \\
\text { energy, Gcal }\end{array}$ & $\begin{array}{c}\text { f.11 - mtp, } \\
\text { Calculation of } \\
\text { specific fuel } \\
\text { consumption } \\
\text { rates for thermal } \\
\text { energy } \\
\text { production }\end{array}$ & 165.02 & 166.34 & 168.37 \\
\hline 3 & $\begin{array}{l}\text { Actual (regulatory) } \\
\text { specific costs of } \\
\text { electricity for the } \\
\text { production of } 1 \text { Gcal of } \\
\text { heat, } \mathrm{kW} \cdot \mathrm{h} / \mathrm{Gcal}\end{array}$ & $\begin{array}{c}\text { Electricity } \\
\text { consumption, } \\
\mathrm{kW} \cdot \mathrm{h}\end{array}$ & $\begin{array}{l}\text { f. No. } 11-\text { mtp, } \\
\text { f. No. } 1 \text { - tep }\end{array}$ & 42.05 & 47.94 & 58.19 \\
\hline
\end{tabular}
of Lviv Polytechnic National University 
Continuation of Table 1

\begin{tabular}{|c|c|c|c|c|c|c|}
\hline 1 & 2 & 3 & 4 & 5 & 6 & 7 \\
\hline 4 & $\begin{array}{l}\text { Actual specific } \\
\text { consumption of natural } \\
\text { gas for the production of } \\
1 \text { Gcal of heat, } \mathrm{m}^{3} / \mathrm{Gcal}\end{array}$ & $\begin{array}{c}\text { Natural gas } \\
\text { consumption, } \mathrm{m}^{3} \\
-\begin{array}{c}\text { Supply of thermal } \\
\text { energy, Gcal }\end{array}\end{array}$ & $\begin{array}{c}\text { f.11- mtp, } \\
\text { f. } 4-\mathrm{mtp} \text { (annual) }\end{array}$ & 142.26 & 143.40 & 145.14 \\
\hline 5 & $\begin{array}{c}\text { Actual specific } \\
\text { consumption of firewood } \\
\text { for the production of } 1 \\
\text { Gcal of thermal energy, } \\
\mathrm{kg} \text {. of conv. fuel/ Gcal }\end{array}$ & $\begin{array}{c}\text { Consumption of } \\
\text { firewood, } \mathrm{m}^{3}\end{array}$ & $\begin{array}{l}\text { f. No. } 11-\text { mtp, } \\
\text { f. No. } 1-\text { tep }\end{array}$ & 0 & 0 & 0 \\
\hline 6 & $\begin{array}{l}\text { The ratio of regulatory } \\
\text { specific and actual FER } \\
\text { costs (K2) }\end{array}$ & $\begin{array}{l}\text { Regulatory specific } \\
\text { costs of conventional } \\
\text { fuel for the } \\
\text { production of } 1 \mathrm{Gcal} \\
\text { of thermal energy, } \\
\mathrm{kg} \text {. of conv. fuel/Gcal } \\
\text { Actual specific } \\
\text { consumption of } \\
\text { conventional fuel for } \\
\text { the production of } \\
1 \text { Gcal of thermal } \\
\text { energy, } \\
\text { kg.of conv.fuel/Gcal }\end{array}$ & $\begin{array}{l}\text { f. No. } 11-\mathrm{mtp} \text {, } \\
\text { f. No. } 1 \text { - tep }\end{array}$ & 1.0279 & 1.0274 & 1.0275 \\
\hline 7 & $\begin{array}{c}\text { The average efficiency of } \\
\text { boilers, } \%\end{array}$ & $\begin{array}{c}\Sigma\left(\mathrm{q}_{1} \mathrm{a}_{1}+\ldots+\mathrm{q}_{\mathrm{n}} \mathrm{a}_{\mathrm{n}}\right) \\
\mathrm{N}\end{array}$ & $\begin{array}{l}\text { Calculation of } \\
\text { specific fuel and } \\
\text { electricity } \\
\text { consumption } \\
\text { rates for heat } \\
\text { production }\end{array}$ & 87.5 & 89.2 & 88.5 \\
\hline 8 & $\begin{array}{c}\text { The share of innovative } \\
\text { technological processes in } \\
\text { heat supply, } \%\end{array}$ & $\begin{array}{c}\text { Heat supply by } \\
\text { modernized boiler- } \\
\text { houses, Gcal } \\
\text { - } \\
\text { Production and } \\
\text { supply of thermal } \\
\text { energy, Gcal }\end{array}$ & $\begin{array}{l}\text { f. No. } 11-\text { mtp, } \\
\text { f. No. } 1 \text { - tep }\end{array}$ & 0.22 & 0.23 & 0.21 \\
\hline 9 & $\begin{array}{c}\text { Share of heat } \\
\text { consumption for own } \\
\text { needs (K4) (normative - } \\
0,009)\end{array}$ & $\begin{array}{l}\text { Thermal energy is } \\
\text { consumed for own } \\
\text { needs of boiler- } \\
\text { houses, Gcal } \\
- \text { Production and } \\
\text { supply of thermal } \\
\text { energy, Gcal }\end{array}$ & f. No. 1 - tep & 0.015 & 0.022 & 0.035 \\
\hline 10 & $\begin{array}{l}\text { Energy intensity of } \\
\text { products }\end{array}$ & $\begin{array}{c}\text { Consumption of FER, } \\
\text { thousand UAH } \\
- \text { Volume of services } \\
\text { provided, thousand } \\
\text { UAH }\end{array}$ & $\begin{array}{l}\text { f. No. } 1 \text {-tep, } \\
\text { (Materials of the } \\
\text { rector's report, } \\
\text { 2020) }\end{array}$ & 0.470 & 0.404 & 0.341 \\
\hline
\end{tabular}


Continuation of Table 1

\begin{tabular}{|c|c|c|c|c|c|c|}
\hline 1 & 2 & 3 & 4 & 5 & 6 & 7 \\
\hline 11 & $\begin{array}{l}\text { Nitrogen oxide emission } \\
\quad \text { standard (K7) }\end{array}$ & $\begin{array}{c}\text { Actual standard } \\
\text { emissions of nitrogen } \\
\text { per } 1 \text { Gcal of heat, } \\
\text { g/Gcal } \\
\text {------------- } \\
\text { Regulatory specific } \\
\text { emissions of nitrogen } \\
\text { per } 1 \text { Gcal of heat, } \\
\text { g/Gcal }\end{array}$ & $\begin{array}{c}\text { Documents } \\
\text { substantiating the } \\
\text { volume of } \\
\text { emissions of } \\
\text { boilers into the } \\
\text { atmosphere to } \\
\text { obtain permits for } \\
\text { emissions } \\
\text {---------- } \\
\text { Indicators of } \\
\text { pollutant emissions } \\
\text { during natural gas } \\
\text { combustion MPC } \\
\text { 34.02.305-2002 }\end{array}$ & 1.513 & 1.565 & 1.520 \\
\hline 12 & $\begin{array}{l}\text { Carbon oxide emission } \\
\text { standard (K8) }\end{array}$ & $\begin{array}{c}\text { Actual regulatory } \\
\text { carbon emissions per } \\
1 \text { Gcal of heat, } \\
\text { g/Gcal } \\
\text { Regulatory specific } \\
\text { carbon emissions per } \\
1 \text { Gcal of heat, } \\
\text { g/Gcal }\end{array}$ & $\begin{array}{c}\text { Documents } \\
\text { substantiating the } \\
\text { volume of } \\
\text { emissions of } \\
\text { boilers into the } \\
\text { atmosphere to } \\
\text { obtain permits for } \\
\text { emissions } \\
\text {----------- } \\
\text { Indicators of } \\
\text { pollutant emissions } \\
\text { during natural gas } \\
\text { combustion MPC } \\
\text { 34.02.305 - 2002 }\end{array}$ & 0.947 & 0.993 & 0.9731 \\
\hline 13 & $\begin{array}{l}\text { Heat loss coefficient with } \\
\text { exhaust gases (K5) }\end{array}$ & $\begin{array}{c}\text { Heat consumption } \\
\text { with exhaust gases, } \\
\text { Gcal } \\
\text { Production and } \\
\text { supply of thermal } \\
\text { energy, Gcal }\end{array}$ & Mode maps & 0.0974 & 0.0972 & 0.0961 \\
\hline 14 & $\begin{array}{l}\text { The coefficient of heat } \\
\text { loss to the environment (K6) }\end{array}$ & $\begin{array}{l}\text { Heat consumption to } \\
\text { the environment, Gcal } \\
\text { Production and } \\
\text { supply of thermal } \\
\text { energy, Gcal }\end{array}$ & Mode maps & 0.00845 & 0.00886 & 0.00881 \\
\hline 15 & $\begin{array}{l}\text { Heat loss coefficient }(\mathrm{K} 3) \\
\text { or }(\mathrm{K} 4+\mathrm{K} 5+\mathrm{K} 6)\end{array}$ & $\begin{array}{c}\text { Consumption of } \\
\text { thermal energy in the } \\
\text { production and supply } \\
\text { of thermal energy, } \\
\text { Gcal } \\
\text { Production and } \\
\text { supply of thermal } \\
\text { energy, Gcal }\end{array}$ & $\begin{array}{l}\text { Mode maps, } \\
\text { f. No. } 1 \text { - tep }\end{array}$ & 0.131 & 0.141 & 0.154 \\
\hline
\end{tabular}


Continuation of Table 1

\begin{tabular}{|c|c|c|c|c|c|c|}
\hline 1 & 2 & 3 & 4 & 5 & 6 & 7 \\
\hline 16 & $\begin{array}{l}\text { Share of reduction of } \\
\text { natural gas consumption } \\
\text { due to modernization of } \\
\text { production or introduction } \\
\text { of energy efficiency } \\
\text { measures, etc. (K11) }\end{array}$ & $\begin{array}{l}\text { Natural gas savings, } \\
\text { thous. } \mathrm{m}^{3}\end{array}$ & $\begin{array}{l}\text { Calculation of } \\
\text { specific fuel and } \\
\text { electricity } \\
\text { consumption rates } \\
\text { for heat production }\end{array}$ & 0.026 & 0.027 & 0.027 \\
\hline 17 & $\begin{array}{l}\text { Coefficient of reduction } \\
\text { of thermal pollution at } \\
\text { introduction of } \\
\text { cogeneration installations } \\
\text { (standard level }(0.2-2 \%) \\
\text { (K10) }\end{array}$ & $\begin{array}{l}\text { Volume of heat } \\
\text { utilization by } \\
\text { cogeneration units, } \\
\text { tubular heat exchange } \\
\text { units and devices, } \\
\text { Gcal } \\
\text { Volume of heat } \\
\text { energy losses to the } \\
\text { environment and with } \\
\text { exhaust gases, Gcal }\end{array}$ & $\begin{array}{l}\text { Calculation of } \\
\text { specific fuel and } \\
\text { electricity } \\
\text { consumption rates } \\
\text { for heat production }\end{array}$ & - & - & - \\
\hline 18 & $\begin{array}{l}\text { Coefficient of utilization } \\
\text { of combustion products } \\
\text { during the introduction of } \\
\text { ash traps, etc. (K9) }\end{array}$ & $\begin{array}{c}\text { Volume reduction of } \\
\text { particulate matter } \\
\text { emissions, } \\
\text { g/Gcal } \\
\text { Volume of particulate } \\
\text { emissions before the } \\
\text { introduction of } \\
\text { equipment, } \\
\text { g/Gcal }\end{array}$ & $\begin{array}{l}\text { Calculation of } \\
\text { specific fuel and } \\
\text { electricity } \\
\text { consumption rates } \\
\text { for heat production }\end{array}$ & - & - & - \\
\hline \multicolumn{7}{|c|}{ Criterion "Energy Independence" } \\
\hline 19 & $\begin{array}{l}\text { The share of own } \\
\text { electricity production by } \\
\text { cogeneration units in total } \\
\text { consumption (K13) }\end{array}$ & $\begin{array}{c}\text { Electricity } \\
\text { production by } \\
\text { cogeneration units, } \\
\text { thous. } \mathrm{kW} \cdot \mathrm{h} \\
- \text { Electricity }^{-} \\
\text {production, thous. } \\
\mathrm{kW} \cdot \mathrm{h}\end{array}$ & $\begin{array}{l}\text { f. No. } 11 \text { - mtp, } \\
\text { f. No. } 1 \text { - tep }\end{array}$ & - & - & - \\
\hline 20 & $\begin{array}{l}\text { Coefficient of use of local } \\
\text { energy resources } \\
\text { (electricity + biomass) in } \\
\text { the consumption structure } \\
\text { (K16) }\end{array}$ & $\begin{array}{c}\text { Use of local FER, } \\
\mathrm{kg} \text {. of conv. fuel } \\
\text { Used FER, } \\
\mathrm{kg} \text {. of conv. fuel } \\
\end{array}$ & $\begin{array}{l}\text { f. No. } 11-\text { mtp, } \\
\text { f. No. } 1 \text {-tep }\end{array}$ & - & - & - \\
\hline 21 & $\begin{array}{l}\text { The share of electricity in } \\
\text { the consumption structure } \\
\text { of FER (K14) }\end{array}$ & $\begin{array}{c}\text { Used electricity, MJ } \\
\text { Used FER, MJ }\end{array}$ & $\begin{array}{l}\text { f. No. } 11-\text { mtp, } \\
\text { f. No. } 1 \text { - tep }\end{array}$ & 0.215 & 0.252 & 0.265 \\
\hline 22 & $\begin{array}{l}\text { The share of renewable } \\
\text { FER in the structure of } \\
\text { consumption (K15) }\end{array}$ & $\begin{array}{c}\text { Used regenerative } \\
\text { FER } \\
\text { kg. of conv. fuel } \\
\text { Used FER, } \\
\text { kg. of conv.fuel }\end{array}$ & $\begin{array}{l}\text { f. No. } 11-\text { mtp, } \\
\text { f. No. } 1 \text { - tep }\end{array}$ & 0.00058 & 0.00064 & 0.00069 \\
\hline
\end{tabular}


Continuation of Table 1

\begin{tabular}{|c|c|c|c|c|c|c|}
\hline 1 & 2 & 3 & 4 & 5 & 6 & 7 \\
\hline 23 & $\begin{array}{c}\text { The share of imported } \\
\text { FER (natural gas) in the } \\
\text { consumption structure } \\
\text { (K12) }\end{array}$ & $\begin{array}{c}\text { Used natural gas, kg. } \\
\text { of conv. fuel } \\
\text { Used FER, } \\
\text { kg. of conv. fuel }\end{array}$ & $\begin{array}{l}\text { f. No. } 11 \text { - mtp, } \\
\text { f. No. } 1 \text { - tep }\end{array}$ & 0.49 & 0.41 & 0.41 \\
\hline 24 & $\begin{array}{l}\text { The share of the largest } \\
\text { supply in the consumption } \\
\text { of FER from one supplier } \\
\text { (K19) }\end{array}$ & $\begin{array}{l}\text { The volume of the } \\
\text { largest use of FER } \\
\text { from one supplier } \\
\text { Used FER } \\
\text { kg. of conv. fuel }\end{array}$ & $\begin{array}{l}\text { f. No. } 11-\text { mtp, } \\
\text { f. No. } 1 \text { - tep }\end{array}$ & 0.475 & 0.407 & 0.411 \\
\hline \multicolumn{7}{|c|}{ Criterion "Energy supply" } \\
\hline 25 & $\begin{array}{l}\text { The share of secondary } \\
\text { energy resources in the } \\
\text { structure of consumption } \\
\text { (K17) }\end{array}$ & $\begin{array}{c}\text { Used secondary FER, } \\
\mathrm{kg} \text {. of conv. fuel } \\
\text { Used FER, } \\
\mathrm{kg} \text {. of conv. fuel }\end{array}$ & $\begin{array}{l}\text { f. No. } 11-\text { mtp, } \\
\text { f. No. } 1 \text { - tep }\end{array}$ & 0 & 0 & 0 \\
\hline 26 & $\begin{array}{c}\text { The share of waste in the } \\
\text { consumption structure of } \\
\text { FER (K18) }\end{array}$ & $\begin{array}{l}\text { Used solid (liquid) } \\
\text { waste, kg.of conv. } \\
\text { fuel } \\
\text { Used FER, } \\
\text { kg. of conv. fuel }\end{array}$ & $\begin{array}{l}\text { f. No. } 11-\text { mtp, } \\
\text { f. No. } 1 \text { - tep }\end{array}$ & 0 & 0 & 0 \\
\hline 27 & $\begin{array}{l}\text { The share of the } \\
\text { confirmed volume of } \\
\text { electricity supply (K21) }\end{array}$ & $\begin{array}{c}\text { Volume of electricity } \\
\text { supply under } \\
\text { concluded contracts, } \\
\mathrm{kW} \cdot \mathrm{h}\end{array}$ & $\begin{array}{l}\text { f. No. } 11-\text { mtp, } \\
\text { f. No. } 1 \text { - tep }\end{array}$ & 1 & 1 & 1 \\
\hline 28 & $\begin{array}{c}\text { Share of confirmed } \\
\text { natural gas supply (K22) }\end{array}$ & $\begin{array}{l}\text { The volume of natural } \\
\text { gas supply under the } \\
\text { concluded } \\
\text { agreements, thous. } \mathrm{m}^{3} \\
\text { Regulatory } \\
\text { consumption of } \\
\text { natural gas, thous. } \mathrm{m}^{3}\end{array}$ & $\begin{array}{l}\text { f. No. } 11-\text { mtp, } \\
\text { f. No. } 1 \text { - tep }\end{array}$ & 1 & 1 & 1 \\
\hline 29 & $\begin{array}{l}\text { Share of confirmed } \\
\text { volume of solid fuel } \\
\text { (biomass) supply (K23) }\end{array}$ & $\begin{array}{c}\text { The volume of supply } \\
\text { of solid wood raw } \\
\text { materials under the } \\
\text { concluded contracts, } \\
\mathrm{m}^{3} \\
\text { Regulatory } \\
\text { consumption of wood } \\
\text { raw materials, } \mathrm{m}^{3}\end{array}$ & $\begin{array}{l}\text { f. No. } 11-\text { mtp, } \\
\text { f. No. } 1 \text { - tep }\end{array}$ & 0 & 0 & 0 \\
\hline
\end{tabular}


Continuation of Table 1

\begin{tabular}{|c|c|c|c|c|c|c|}
\hline 1 & 2 & 3 & 4 & 5 & 6 & 7 \\
\hline \multicolumn{7}{|c|}{ Criterion "Reliability of heat supply" } \\
\hline 30 & $\begin{array}{l}\text { Coefficient of suitability } \\
\text { of fixed assets (K24) }\end{array}$ & $\begin{array}{c}\text { Residual value of } \\
\text { fixed assets, thousand, } \\
\text { UAH } \\
\text { Initial cost of fixed } \\
\text { assets, thousand, UAH }\end{array}$ & f. No. $1-\mathrm{m}$ & 0.6866 & 0.6635 & 0.6060 \\
\hline 31. & $\begin{array}{l}\text { The share of fixed assets } \\
\text { with a service life of more } \\
\text { than } 20 \text { years }(\mathrm{K} 25)\end{array}$ & $\begin{array}{c}\text { Initial cost of fixed } \\
\text { assets with a service } \\
\text { life of more than } 20 \\
\text { years, thousand UAH } \\
\text {------------ } \\
\text { Initial cost of fixed } \\
\text { assets, thousand UAH }\end{array}$ & f. No. $1-\mathrm{m}$ & 0.9177 & 0.9538 & 0.987 \\
\hline 32 & $\begin{array}{l}\text { Coefficient of use of the } \\
\text { installed capacity of } \\
\text { boiler-houses (boiler } \\
\text { units)(K26) }\end{array}$ & $\begin{array}{l}\text { Boiler capacity at the } \\
\text { end of the year, Gcal/h } \\
\text { Total productivity of } \\
\text { boiler houses at the } \\
\text { end of the year, Gcal/h }\end{array}$ & $\begin{array}{c}\text { ф. No. } 11-\text { mtp, } \\
\text { ф. No. } 1 \text { - tep }\end{array}$ & 0.46 & 0.46 & 0.46 \\
\hline 33 & $\begin{array}{l}\text { Coefficient of loading of } \\
\text { the equipment of the main } \\
\text { (auxiliary) production } \\
\text { processes (K27) }\end{array}$ & $\begin{array}{c}\Sigma\left(\mathrm{q}_{\mathrm{i}} \cdot \mathrm{T}_{\mathrm{i}}\right) / \Sigma \mathrm{t}_{\mathrm{i}}, \text { where } \\
\mathrm{q}_{\mathrm{i}}-\text { loading of the } i \text {-th } \\
\text { unit of equipment, } \\
\mathrm{T}_{\mathrm{i}}-\text { the actual } \\
\text { performance of the } \\
i \text {-th unit of equipment }\end{array}$ & Mode maps & 0.315 & 0.310 & 0.248 \\
\hline 34 & $\begin{array}{l}\text { Coefficient of heat losses } \\
\text { during transportation } \\
\text { (K28) (norm not higher } \\
\text { than } 6 \% \text { ) }\end{array}$ & $\begin{array}{c}\text { Thermal energy is } \\
\text { released to consumers, } \\
\text { Gcal } \\
\text { Released thermal } \\
\text { energy, Gcal }\end{array}$ & f. No. 1 - tep & 0.036 & 0.036 & 0.037 \\
\hline 35 & $\begin{array}{l}\text { The share of emergency } \\
\text { heating networks (K29) }\end{array}$ & $\begin{array}{l}\text { The length of } \\
\text { emergency heat and } \\
\text { steam networks in the } \\
\text { pipeline calculation at } \\
\text { the end of the year } \\
\text { The length of heat } \\
\text { and steam networks } \\
\text { in two-pipe calculation } \\
\text { at the end of the year }\end{array}$ & f. No. 1 - tep & 0.43 & 0.43 & 0.38 \\
\hline
\end{tabular}


Continuation of Table 1

\begin{tabular}{|c|c|c|c|c|c|c|}
\hline 1 & 2 & 3 & 4 & 5 & 6 & 7 \\
\hline 36 & $\begin{array}{l}\text { Ratio of investments and } \\
\text { capital investments to the } \\
\text { volume of heat supply } \\
\text { (K30) (not less than } 5 \% \text { ) }\end{array}$ & $\begin{array}{c}\text { Volume of } \\
\text { investments in } \\
\text { modernization of } \\
\text { production, thousand } \\
\text { UAH } \\
\begin{array}{c}\text { Regulatory revenues in } \\
\text { total for production, } \\
\text { thousand UAH }\end{array}\end{array}$ & $\begin{array}{l}\text { Information on the } \\
\text { implementation of } \\
\text { the Energy } \\
\text { Efficiency } \\
\text { Program for } \\
\text { 2017-2019. }\end{array}$ & 0.039 & 0.031 & 0.022 \\
\hline 37 & $\begin{array}{l}\text { The coefficient of } \\
\text { recovery of the } \\
\text { technological resource of } \\
\text { fixed assets (K31) }\end{array}$ & $\begin{array}{c}\Sigma\left(\mathrm{c}_{\mathrm{i}} * \mathrm{~b}_{\mathrm{i}}\right) / \Sigma \mathrm{b}_{\mathrm{i}}, \text { де } \mathrm{c}_{\mathrm{i}}- \\
\text { the ratio of } \\
\text { technological } \\
\text { resource of the } i \text {-th } \\
\text { unit of fixed assets, } \\
\mathrm{b}_{\mathrm{i}}-\text { specific weight in } \\
\text { the residual value of } \\
\text { the } \mathrm{i} \text {-th unit of } \\
\text { recovery }\end{array}$ & $\begin{array}{l}\text { Information on the } \\
\text { implementation of } \\
\text { the Energy } \\
\text { Efficiency } \\
\text { Program for } \\
\text { 2017-2019. }\end{array}$ & 0.077 & 0.029 & 0.086 \\
\hline 38 & $\begin{array}{l}\text { Share of renewed and } \\
\text { modernized heating } \\
\text { networks (K32) }\end{array}$ & $\begin{array}{l}\text { The length of the } \\
\text { replaced heat and } \\
\text { steam networks, m } \\
- \\
\text { The length of thermal } \\
\text { and steam networks, } m\end{array}$ & $\begin{array}{l}\text { f. No. } 11-\text { mtp, } \\
\text { f. No. } 1 \text { - tep }\end{array}$ & 0.57 & 0.57 & 0.62 \\
\hline \multicolumn{7}{|c|}{ Criterion "Economic stability" } \\
\hline 39 & $\begin{array}{l}\text { The share of costs for } \\
\text { emergency and recovery } \\
\text { works in the cost of } \\
\text { providing heat supply } \\
\text { services (K33) }\end{array}$ & $\begin{array}{l}\text { Costs for emergency } \\
\text { and recovery works, } \\
\text { thousand UAH } \\
\text { Cost of providing } \\
\text { heat supply services, } \\
\text { thousand UAH }\end{array}$ & $\begin{array}{l}\text { Data from } \\
\text { accounting and } \\
\text { energy } \\
\text { management } \\
\text { services }\end{array}$ & 0.024 & 0.026 & 0.039 \\
\hline 40 & $\begin{array}{l}\text { The share of the cost of } \\
\text { natural gas in the cost of } \\
\text { providing heat supply } \\
\text { services (K35) }\end{array}$ & $\begin{array}{c}\text { Cost of consumed } \\
\text { natural gas, thousand } \\
\text { UAH } \\
--------------- \\
\text { Actual cost of } \\
\text { providing heat supply } \\
\text { services, thousand } \\
\text { UAH }\end{array}$ & $\begin{array}{l}\text { Interpretation of } \\
\text { costs in tariffs for } \\
\text { heat supply }\end{array}$ & 0.86 & 0.83 & 0.81 \\
\hline 41 & $\begin{array}{c}\text { The ratio of the regulated } \\
\text { price of natural gas to the } \\
\text { market (K36) }\end{array}$ & $\begin{array}{l}\text { The price of natural } \\
\text { gas for the university, } \\
\text { thousand UAH. } \\
\text { Price of natural gas } \\
\text { supply for other } \\
\text { consumers, thousand } \\
\text { UAH }\end{array}$ & $\begin{array}{l}\text { (Official site of } \\
\text { NJSC Naftogaz of } \\
\text { Ukraine, 2017) }\end{array}$ & 0.97 & 1.07 & 1.07 \\
\hline
\end{tabular}


End of Table 1

\begin{tabular}{|c|c|c|c|c|c|c|}
\hline 1 & 2 & 3 & 4 & 5 & 6 & 7 \\
\hline 42 & $\begin{array}{l}\text { University debt ratio for } \\
\text { consumed natural gas } \\
\text { (K37) }\end{array}$ & $\begin{array}{c}\text { Debt on settlements } \\
\text { for natural gas at the } \\
\text { end of the year, } \\
\text { thousand UAH } \\
\text {-------- } \\
\text { Cost of consumed } \\
\text { natural gas, thousand } \\
\text { UAH }\end{array}$ & $\begin{array}{l}\text { f. No. } 11-\text { mtp, } \\
\text { f. No. } 1 \text { - tep }\end{array}$ & 0 & 0 & 0 \\
\hline 43 & $\begin{array}{l}\text { The ratio of regulated } \\
\text { tariff to market }(K 40)\end{array}$ & $\begin{array}{l}\text { Tariff for thermal } \\
\text { energy for institutions } \\
\text { maintained at the } \\
\text { expense of budget } \\
\text { funds, UAH/Gcal } \\
\text {------------------- } \\
\text { Tariff for thermal } \\
\text { energy for other } \\
\text { enterprises, UAH/Gcal }\end{array}$ & $\begin{array}{l}\text { f. No. } 11-\text { mtp, } \\
\text { f. No. } 1-\text { tep } \\
\text { f. No. } 1-\mathrm{m} \text {, } \\
\text { (Official site of the } \\
\text { State Agency for } \\
\text { Energy Efficiency }\end{array}$ & 0.80 & 1.107 & 0.986 \\
\hline 44 & Wage arrears ratio (K44) & $\begin{array}{l}\text { Current liabilities for } \\
\text { payroll calculations at } \\
\text { the end of the year, } \\
\text { thousand UAH } \\
\text {---------------------- } \\
\text { Labor costs, thousand } \\
\text { UAH }\end{array}$ & f. No. $1-\mathrm{m}$ & 1 & 1 & 1 \\
\hline 45 & $\begin{array}{c}\text { The share of the cost of } \\
\text { natural gas in the tariff for } \\
\text { its purchase }(\mathrm{K} 42)\end{array}$ & $\begin{array}{l}\text { The cost of natural } \\
\text { gas without VAT and } \\
\text { transportation tariffs, } \\
\text { UAH / } 1000 \mathrm{~m}^{2} \\
\text {--------------------- } \\
\text { Tariff for the purchase } \\
\text { of natural gas for } \\
\text { budget organizations, } \\
\text { UAH/1000 m² }\end{array}$ & $\begin{array}{l}\text { (NERC official } \\
\text { website, 2020) }\end{array}$ & 0.82 & 0.83 & 0.830 \\
\hline 46 & $\begin{array}{l}\text { The share of the cost of } \\
\text { electricity in the tariff for } \\
\text { heat }(\mathrm{K} 43)\end{array}$ & $\begin{array}{l}\text { Electricity costs, } \\
\text { thousand UAH. } \\
\text { Thermal energy } \\
\text { released, thousand } \\
\text { UAH }\end{array}$ & $\begin{array}{c}\text { Data from } \\
\text { accounting and } \\
\text { energy } \\
\text { management } \\
\text { services }\end{array}$ & 0.06 & 0.05 & 0.03 \\
\hline
\end{tabular}

Using the values of the weights of energy security in Table 1, we determine:

$\ddot{y}$ indicator of energy efficiency of the university (EE) according to the formula:

$$
E E=\frac{K_{1} \cdot K_{2} \cdot\left(1-K_{3}\right) \cdot\left(1+K_{9}\right) \cdot\left(1+K_{10} \cdot\left(K_{5}+K_{6}\right)\right)}{K_{7} \cdot K_{8}} ;
$$

$\ddot{y}$ indicator of energy independence of the university (EI):

$$
\mathrm{EI}=\left(1+\mathrm{K}_{11} \cdot \mathrm{K}_{12}\right) \cdot\left(\mathrm{K}_{13} \cdot \mathrm{K}_{14}+\mathrm{K}_{15}+\mathrm{K}_{16}+\mathrm{K}_{17}+\mathrm{K}_{18}\right) \cdot\left(1-\mathrm{K}_{19}\right) ;
$$

$\ddot{y}$ indicator of energy supply of the university (ES):

$$
\mathrm{ES}=\mathrm{K}_{15} \cdot \mathrm{K}_{23}+\mathrm{K}_{12} \cdot \mathrm{K}_{22}+\mathrm{K}_{14} \cdot \mathrm{K}_{21}+\mathrm{K}_{18}+\mathrm{K}_{17} \text {; }
$$

$\ddot{y}$ indicator of reliability of heat supply of the university (RH):

$$
\mathrm{RH}=\mathrm{K}_{24} \cdot\left(1-\mathrm{K}_{25}\right) \cdot \frac{\mathrm{K}_{26}}{\mathrm{~K}_{27}} \cdot \frac{\mathrm{K}_{26 \mathrm{H}}}{\mathrm{K}_{26 \phi}} \cdot\left(1-\mathrm{K}_{28}\right) \cdot\left(1-\mathrm{K}_{29}\right) \cdot \frac{\mathrm{K}_{30 \phi}}{\mathrm{K}_{30 \mathrm{H}}} \cdot\left(1+\mathrm{K}_{31}\right) \cdot\left(1+\frac{\mathrm{K}_{329}}{\mathrm{~K}_{29}}\right) \text {; }
$$


$\ddot{y}$ indicator of economic stability of the university (ES):

$$
\mathrm{ES}=\left(1-\mathrm{K}_{33}\right) \cdot \mathrm{K}_{40} \cdot \mathrm{K}_{35} \cdot \mathrm{K}_{42} \cdot \mathrm{K}_{36} \cdot\left(1-\mathrm{K}_{37}\right) \cdot\left(1-\mathrm{K}_{44}\right) .
$$

The results of the calculations are entered in Table 2.

Energy security levels of Lviv Polytechnic National University

\begin{tabular}{|l|r|r|r|}
\hline \multirow{2}{*}{ Criteria } & \multicolumn{3}{c|}{ Years } \\
\cline { 2 - 4 } & \multicolumn{1}{c|}{2017} & \multicolumn{1}{c|}{2018} & \multicolumn{1}{c|}{2019} \\
\hline Energy efficiency (EE) & 0.55238 & 0.50258 & 0.52043 \\
\hline Energy independence (EI) & 0.00031 & 0.00038 & 0.00041 \\
\hline Energy security (ES) & 0.70041 & 0.66099 & 0.67845 \\
\hline Reliability of heat supply (RH) & 0.19081 & 0.07876 & 0.05882 \\
\hline Economic stability (ES) & 0.52967 & 0.8026 & 0.68053 \\
\hline
\end{tabular}

Assessments of energy security indicators of the university showed the following results:

1. Assessment of energy efficiency of the university.

The level of energy efficiency for the studied period varies at the level of: $0.52-0.55$, which is explained by the presence of large losses in energy conversion, because of the fact that the university has not replaced energy-intensive boilers with low energy conversion.

2. Assessment of energy independence of the university.

The energy independence indicator is at the lowest level: $0.00031-0.00041$, which is explained by:

$\ddot{y}$ Reduction of the share of natural gas consumption by only $2.7 \%$, as low-capacity boilers were replaced, so in the future it is necessary to replace energy-intensive boilers.

$\ddot{y} \quad$ Lack of electricity production by cogeneration units, which significantly reduces the rate of energy independence.

$\ddot{y} \quad$ Lack of FER production using cogeneration, local FER, such as biomass, secondary energy resources, waste in the consumption structure and a small share of energy resources using renewable energy.

3. Assessment of energy supply of the university.

The energy supply index of the university for the studied period is at the level: $0.66-0.7$. This is due to the following:

$\ddot{y} \quad$ Small share of FER in the consumption structure.

$\ddot{y} \quad$ Lack of heat supply on other types of FER.

$\ddot{y}$ Small share of secondary FER in the consumption structure

$\ddot{y} \quad$ No waste in the consumption structure.

4. Assessment of the reliability of heat supply of the university

During the study period, the reliability of heat supply decreases (0.19-0.058), which is explained by:

$\ddot{y} \quad$ Insufficient measures to restore the material and technical base.

$\ddot{y} \quad$ Low level of suitability of fixed assets, which indicates the need for more intensive updating of material and technical base.

$\ddot{y} \quad$ A large share of fixed assets with a service life of more than 20 years is $(96 \%)$.

$\ddot{y}$ Low load factor of power generating equipment is operated, which significantly affects the increase of energy consumption.

$\ddot{y} \quad$ A large share of emergency heating networks and a low recovery rate of technological resources of fixed assets require more intensive renewal.

5. Assessment of economic stability of the university:

The share of emergency recovery work is constantly growing, which is explained by:

$\ddot{y} \quad$ Significant age of engineering equipment and networks. 
$\ddot{y} \quad$ The small ratio of the regulated tariff for gas supply to the market fluctuates in the range of 0.8-1.107, which means the lack of state regulation for organizations in the public sector.

According to the results of the provided research, the following measures are proposed to improve the energy security of the university:

1. Displacement of own generation with the use of: wind and solar, cogeneration, secondary energy resources.

2. Reduction of specific costs of fuel and energy resources through complete energy modernization of buildings (including the installation of individual heating stations with weatherdependent automation, replacement of heating systems, insulation of building facades and replacement of existing windows with metal-plastic energy efficient, replacement of ventilation systems).

3. Replacement of obsolete boiler equipment with modern energy-saving equipment from leading European manufacturers such as Viessmann, Bosh, Prothetm and others.

4. Continuation of the replacement of the existing lighting of educational and scientific laboratories and classrooms with energy-saving LED lighting.

5. Replacement of existing heating networks using pre-insulated pipelines.

6. Adjustment of the hydraulic mode of thermal networks.

7. Introduction of backup schemes for both electric and thermal flows.

8. Automation of energy flow and the possibility of implementing switching schemes.

9. Improving the reliability and quality of circuits and flows.

10. Full automation of accounting for fuel and energy resources and water, improving the quality of the energy management system.

\section{Conclusions}

As a result of the provided researches, the method of energy security assessment was adapted and tested on the example of the Lviv Polytechnic National University and improving measures were developed. The results of the surveys can be used in the management decision-making process and included in current and future development plans of the university. The obtained numerical research results allow to focus the attention of management staff to eliminate shortcomings in the most problematic areas of the energy sector.

Determining the level of energy security based on the adoption of a general system of comprehensive indicators can be recommended for use in higher education to assess the real state of energy farms, and the proposed method can be used by the State Inspectorate for Energy Inspection of Ukraine in checking the state of energy farms.

\section{References}

Kapitula S. V., Shevchenko S. I., Shpitko V. V. (2010). Methodical approaches to creation of energy safety of the enterprise. Efficient Economy, 8, 2010 (electronic resource). Available at: http://www.economy.nayka. com.ua/?op=1\&z=276

Mazur M. I. (No.1, 2014). Analysis of energy security of the enterprise: theoretical and practical principles. Energy efficient economy, No. 1, 2014.

Methodical recommendations for calculating the level of economic security of Ukraine (electronic resource) (2013). Available at: https://zakon.rada.gov.ua/rada/show/v1277731-13/print.

Mazur I. M. (Vol. 10, T2, 2014). Criteria for assessing energy security: a resource approach./Actual problems of economic development of the region. Vol. 10, T2, 2014. P. 145-153.

Mukolyuk O. A. (2019). Energy security management of enterprises: theory, practice, methodology. Monograph / O. A. Mykolyuk - Khmelnytsky: KNU, 2019. P. 481.

Lelyuk O. V. (2013). Theory and practice of energy security assessment. Lelyuk O. V. // Modeling of the regional economy. 2013. No. 1. P. 239-260. - Access mode: http://nbuv.gov.ua/UJRN/Modre_2013_1_25

Vorontsov S. B., Sidorenko A. A., Smenkovsky A. Y. (2012). Assessment of the state of energy security of Ukraine./ Strategic priorities, No. 2 (23), 2012 p. P. 21-30. 
Barannik V. O. (2012). Energy security of the state: substantiation of the main components, dependencies and interdependencies / Strategic priorities, No. 2 (23), 2012. P. 40-46.

Materials for the report of the Rector of the National University "Lviv Polytechnic" Yu. Ya. Bobal at the Conference of the staff on January 30, 2020 "The main results of the team of NU" Lviv Polytechnic "in 2019" (electronic resource). Available at: https://lpnu.ua/sites/default/files/attach/2020/15203/zvit_rektora_2019.pdf

Official site of NJSC Naftogaz of Ukraine (electronic resource) (2017). Available at: https://www.naftogaz. com/files/Information/Naftogaz-gas-prices-January-2017.pdf

Official site of the State Agency for Energy Efficiency of Ukraine (electronic resource) (2020). Available at: https://saee.gov.ua/uk/content/serednozvazheni-taryfy-2020.pdf

Official website national energy utilities regulatory commission (NERC) of Ukraine (electronic resource) (2020). Available at: https://www.nerc.gov.ua/?id=19611-2020.pdf

Yemelyanov, O., Symak, A., Petrushka, T., Lesyk, R., Lesyk, L. (2018): Assessment of the Technological Changes Impact on the Sustainability of State Security System of Ukraine. Sustainability 10, 1186 (2018).

Yemelyanov, O., Symak, A., Petrushka, T., Zahoretska, O., Kusiy, M., Lesyk, R., Lesyk, L. (2019): Changesin Energy Consumption, Economic Growth and Aspirations for Energy Independence: Sectoral Analysis of Uses of Natural Gasin Ukrainian Economy. Energies 12, 4724 (2019).

В. 3. Пашкевич ${ }^{1}$, М. А. Малашкін ${ }^{2}$, В. М. Желих ${ }^{3}$, О. Ю. Лозинський ${ }^{4}$

${ }^{1}$ Національний університет “Львівська політехніка", кафедра електронних засобів та інформаційно-комп’ютерних технологій;

2 Українська енергетична асоціація,

${ }^{3}$ Національний університет “Львівська політехніка”, кафедра теплогазопостачання та вентиляції,

${ }^{4}$ Національний університет “Львівська політехніка", кафедра електромехатроніки та комп’ютеризованих електромеханічних систем

\section{ОЦІНКА ЕНЕРГЕТИЧНОЇ БЕЗПЕКИ ЗАКЛАДІВ ВИЩОЇ ОСВІТИ}

\section{(C) Пашкевич В. 3., Малашкін М. А., Желих В. М., Лозинський О. Ю., 2021}

Сьогодні відсутні чіткі та грунтовні методики оцінки енергетичної безпеки підприємства. Ці невирішені питання не дають змогу на відповідному рівні управляти безпекою підприємства, що негативно позначається на результатах його господарювання. Ця проблематика особливо актуальна для закладів вищої освіти, що фінансуються з державного бюджету.

Визначення рівня енергетичної безпеки на основі прийнятої загальної системи комплексних показників є однією з умов сталого соціально-економічного та матеріально-технічного розвитку закладів вищої освіти та повинно посилити увагу керівників ЗВО до проблем, пов'язаних із підвищенням енергетичної безпеки.

Нагальна необхідність створення ефективної системи управління процесами енергоспоживання та енергозбереження в галузі освіти та важливість результатів оцінювання енергетичної безпеки для забезпечення сталого розвитку закладів вищої освіти свідчить про об'єктивну необхідність проведення таких обстежень.

У роботі висвітлено обстеження енергетичного господарства Національного університету “Львівська політехніка" з метою оцінки енергетичної безпеки, удосконалення стратегії енерговикористання та розроблення заходів з підвищення енергетичної безпеки університету.

В основу запропонованого методу покладено методику визначення 46 показників, за якими сформовано п'ять критеріїв енергетичної безпеки зокрема такі як: "Енергоефективність", "Енергонезалежність", "Енергозабезпеченість", "Надійність теплопостачання", “Економічна стабільність". За згаданими показниками обчислено значення кожного з перехованих вище критеріїв і проаналізовано іx рівні. На основі цього аналізу запропоновано засади підвищення енергетичної безпеки університету.

Ключові слова: енергетична безпека, енергоефективність, енергонезалежність, енергозабезпеченість, надійність теплопостачання, економічна стабільність, паливно-енергетичні ресурси. 